College Hospital there is at least a recognition of this aspect of the patient and an eagerness to respond to him as a person.

Furthermore, the fact that Mrs A died in the ward made the other patients in 4/3 aware of, and even part of, the final stage of death. I write "the final stage of death" because this is how another patient, Mr B, a philosophical sort, had previously described a person's last hours. As he explained, life is a process of dying for from the moment we are born we begin to die. Therefore, if we struggle with the fact of our death and understand how to die then we will know how to live as well. This is perhaps a too simple idea, but it is right, I think, in the most important sense of what it means to be right. When Mr B was admitted to ward $4 / 3$ he was greatly distressed. After witnessing the death of several patients in the ward in the course of three weeks he was considerably less upset. I don't mean to suggest that if a patient reconciles himself with his anxieties about death then "tout est pour le mieux dans le meilleur des mondes possibles," or that the thought of dying was the cause of his psychological distress. In our initial conversations he seemed partly just ill at ease with his new surroundings. Being in the presence of other dying patients, however, seemed to relieve some of what $\mathrm{Mr}$ B described as "the awful fear of death's awesome mystery."

We (and I mean the royalist "we") have isolated death, removed it along with germs and viruses from our daily lives. Death was never as common around the house as the cold, but children were once as comfortable at play in a graveyard as in the garden behind the town church. We have become xenophobic of death and speak of it as something that is foreign to us. I was told that Mrs A "passed away" and heard that $\operatorname{Dr} C$ "is gone." It is as though to speak directly of death, to call death "death," enacts the word.

My experience with dying patients has been limited in that my role of minstrel usually maintains a distance between me and the patients, and the relationship is similar in this small respect to that between a doctor and a patient. I remember, though, a visit to my grandfather when he was dying in the intensive care unit at Columbia Presbyterian Hospital. I was upset not so much by the tubes feeding him air or by the needles nourishing him with colourless liquid as by a feeling that I was unable to feel his dying. I was told by the nurse not to touch him, not to disturb him. My 10 year old brother was ordered not to come into the room but to watch from the other side of the window. Who was being protected? My brother? My grandfather? The Thursday before Mrs A died she was visited by her son and his children. One of them, a boy of 5, played merrily at Grandma's feet, unconcerned though curious about the happenings. There was a deep acknowledgment when their wide eyes met.

Later in the evening I caught up with the young nurse who had attended to Mrs A at her death. We spoke about the "medic" disco at Camden Palace sponsored to raise money for research into diabetes and of our clever friend who had borrowed an intravenous fluid bottle to dispense gin at the affair. Then I asked her if Mrs A had said anything before dying. The young nurse wondered for the moment of a minute, perhaps as much about my interest in Mrs A as anything else, and replied cautiously that she didn't think so. We talked some more, and I reminded her of the time when old Miss $M$ had said to me, "I don't suppose you'd like to give an old lady a little kiss," and how I had kissed her and said, "I don't suppose you'd like to give a young medic a little kiss," and how she had done. Then I asked, gently, if anything special had happened during Mrs A's death. She was quiet, and I could feel a subtle tension in our silence. I waited. The young nurse said that Mrs A's death was usual. She had sat beside the dying woman, held her hand, and whispered her name.

\title{
The stigmata: pathology or miracle?
}

\section{J SIMPSON}

The medical approach towards religious phenomena is often to categorise them as "illnesses." This may be seen in the diagnosis of St Paul as having epilepsy and of Joan of Arc as having schizophrenia. Is there, however, a pathological process in religious stigmatisation? Stigmata are the wounds of Christ appearing on the body; they may include bleeding marks or holes on the hands, feet, and side and marks on the forehead and shoulder - the sites of the crown of thorns and cross respectively.

Imbert-Gourbeyre found that of the 321 people with stigmata that he discovered since the time of St Francis, 41 were men and 280 were women and these during their reproductive years. They were mainly from Italy, followed by France, Spain, Germany, Belgium, Portugal, Switzerland, Holland, Hungary, and Peru in that order.' Few people with stigmata have been beatified or canonised, and the Catholic Church teaches that there is no intrinsic connection between sanctity and stigmatisation. ${ }^{2}$ The sites of the stigmata are interesting, as the work of Barbet on cadavers $^{3}$ and evidence from the Shroud of Turin ${ }^{4}$ suggest that Christ had nails through his wrists whereas people with stigmata have palm wounds. The site of the lance wound is omitted in the Bible but changes, according to the current belief, from right or left hypochondrium to over the heart in those with stigmata. ${ }^{2}$ The

Drug Dependency Treatment Unit, St George's Hospital, London SW17 0QT C J SIMPSON, MB, BS, registrar wounds tend to change with the years; some bleed permanently and some just on Fridays. They normally appear when the person is in what is called "ecstasy."

St Francis of Assisi (1182 to 1226) is thought to have been the first person to receive stigmata unless St Paul implied that he had them when he wrote "I bear the marks of the Lord Jesus in my body." St Francis developed the stigmata during an ecstatic vision in 1224, when they were seen by a friend, Brother Leo, whose own handwritten note (the authenticity of which is uncontested) vouches for their reality. ${ }^{6}$ They were also seen by many after his death and were described two years after his death in his first biography: "The marks on the hands were round on the inner side, but on the outer side they were elongated: and some small pieces of flesh took on the appearance of the ends of the nails, bent and driven back and rising above the rest of the flesh."

Among famous nineteenth century examples was a Belgian girl called Louise Lateau (1850 to 1883), who bled every Friday except for two from 1868 to 1883 . She was observed by various eminent Belgian doctors. ${ }^{8}$ A German peasant girl called Therese Neumann (1898 to 1962) was bedridden from several head injuries when she developed the stigmata in 1926. Blood started to come from her side during an ecstatic vision, and a few weeks later she developed the hand and feet wounds. From then on they bled regularly on Fridays until her death. ${ }^{9}$ Her doctor diagnosed her initially as having "hysteria traumatica" for insurance purposes, though after the stigmata appeared he changed his mind. ${ }^{10}$

Padre Pio (1887 to 1968) was also of peasant stock. His biographies describe him as always having been spiritually 
oriented and of a frail constitution. He had what seems to have been tuberculosis as a young man, and he fasted, in the opinion of his fellow Franciscans, excessively. ${ }^{11} \mathrm{He}$ developed the stigmata in 1918 and they bled continually afterwards, but faded at the end of his life.

\section{Desire to suffer}

All these examples occurred in deeply religious people, who actually desired to suffer with Christ. They did not seem to seek publicity or material reward-indeed, they often avoided it. Whitlock and Hynes, however, reported on a Polish lady in Australia, who had a devotion to Veronica's Veil and apparently wept blood while in ecstasies. ${ }^{12}$ She did not, it seems, avoid publicity and finally died in 1963 of a barbiturate overdose. Similarly, but even more bizarre, is the case of the $10^{1 / 2}$ year old girl from a black Baptist family reported on by Early and Lifschutz who in 1972 was reported to have had spontaneous bleeding from her left palm initially and later from the right palm, both feet, and thorax. ${ }^{13}$ Unfortunately, no doctor was able to observe the beginning of these episodes so self induced trauma cannot be ruled out, although Early and Lifschutz believe the likelihood of this to be almost nil.

The question of aetiology remains controversial. Self induced wounds - that is, dermatitis artefactaare a common theory. Therese Neumann was observed constantly on several occasions, but this satisfied only the observers, not the critics. In $1875 \mathrm{Dr}$ Warlomont used an ingenious method to observe Louise Lateau. ${ }^{8} \mathrm{He}$ put a glass cylinder over her whole arm and made special seals, which he claimed could not be foiled. $\mathrm{He}$ assembled this on a Thursday, and on the Friday, with the seals unbroken, there was a wound on the hand and blood in the glass bulb.

The evidence suggests that at least some people's stigmata are not self induced. Could physical changes be taking place through psychological mechanisms? Moody reported various episodes of physical changes occurring under abreaction. ${ }^{14}$ is For instance, a man who abreacted about an episode when he had been tied up developed weals and petechial haemorrhages on his forearms where the rope had been. Pattie ${ }^{16}$ and Paul $^{17}$ reviewed reports of the induction of blisters under hypnosis and concluded that, though most experiments lacked good controls, blisters could be induced in some subjects. Needles described a Jewish man with a serious anxiety about castration who developed spontaneous bleeding from his right hand on three occasions when under threat from men. ${ }^{18}$

There is no reason to suppose that all stigmata have the same aetiology. Despite reports of self induced stigmata it seems unlikely that this is always the case. ${ }^{6}$ Dermatographia, which causes an exaggerated triple response, and vicarious menstruation seem unlikely causes. St Francis had malaria, and purpura from this cause has been suggested as the mechanism in his case. ${ }^{19}$ Herpes simplex infection seems to be under emotional control, and it has been suggested that the stigmatic lesions are indeed herpetic. ${ }^{12}$

\section{Hysterical conversion symptoms}

The autoerythrocyte sensitisation syndrome is a rare disease almost exclusively of women who become sensitised to their own red blood cells. They often have a history of psychiatric disease. Ratnoff and Agle reviewed 27 such patients, all of whom gave a similar clinical picture of painful areas becoming red and forming a bruise. ${ }^{20}$ Agle et al looked at six patients with this disease to see if there was any evidence of the haematomas being symptoms of hysterical conversion and concluded that there was in each case. ${ }^{21}$ The interest in the autoerythrocyte sensitisation syndrome with regard to the stigmata is that they are both rare, occur in women during the reproductive years, occur in people with slightly odd personalities with a history of physical illness, and have severe pain associated with the site. ${ }^{22}$

Stigmatisation is often described as being "hysterical." This would depend on what is understood by this word. It is most commonly used in this context to mean hysterical conversion and not hysterical personality disorder. No unanimity exists on the definition of hysterical conversion, but the question here is whether it can be used to describe a physical change due to psychological desire; Freud suggested that it should be motor or sensory disturbances, ${ }^{23}$ and the International Classification of Diseases requires a "psychogenic disturbance of function." ${ }^{24}$ Lord suggested that the unconscious fantasy of those with stigmata

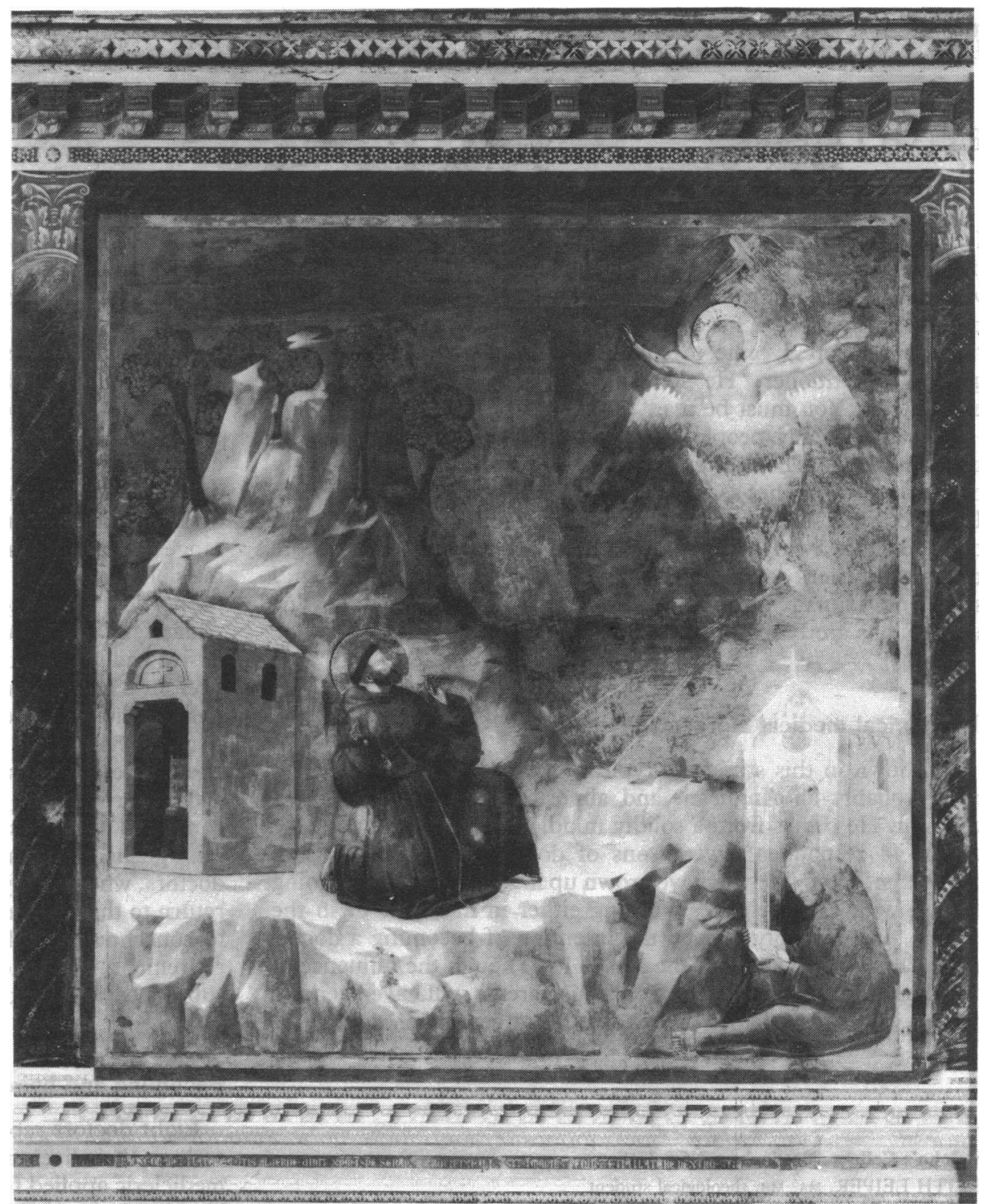

"St Francis receiving the Stigmata" by Giotto. Brother Leo is in the bottom right hand corner. With kind permission of Sacro Convento, Assisi. 
leading to the conversion symptom is that of a woman desiring to be saintly and non-sexual (Christ like). ${ }^{25}$ Ultimately, however, we are just substituting one poorly understood diagnosis (stigmata) with another (hysterical conversion).

The validity of the miracle theory depends primarily on your personal beliefs. But even if you consider it to be possible you then have to consider why God has done this in the past to some rather odd people, why He has imposed ecstasy as an indispensable condition, and why He gives it to people at the varying sites in the abdomen and chest and why in the palms and not the wrists. Furthermore, why should God give the stigmata preferentially to women?

Many attempts have been made to diagnose the stigmata as symptoms of illness without much success. The evidence does suggest, however, that psychological mechanisms play some part in their formation. Theologians seem equally baffled. Whatever your beliefs, the study of the stigmata does typify the fascinating relation between physical, psychological, and spiritual phenomena.

\title{
References
}

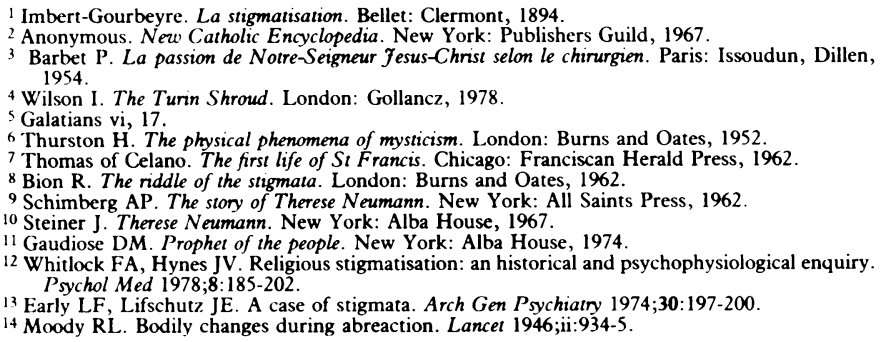

\section{Medical clergy: square pegs in holy holes?}

\author{
KEITH LEIPER
}

It was the first Sunday of my new life as a theological student. I had arrived at the parish church to which I was to be attached. The vicar, to put me at my ease, introduced me to a doctor who was a prominent member of his congregaton, who asked me what my job had been before I came to college. I replied that I had been a general practitioner. He looked at me in astonishment and exclaimed, "You must be mad!"

Nowadays many people make radical changes of direction in mid-life. Doctors have often played a part in the informal ministry of their local churches as deacons, lay preachers, or readers. When I was accepted for training for the Anglican ministry I tried to find other doctors who had either left the practice of medicine to become ministers or combined the roles of doctor and clergyman. I sent questionnaires to 68 medical clergy, and the following impressions are based on the 44 replies that I received.

\section{The typical medical clergyman}

As shown in this study the typical medical clergyman is in his 50s, probably an Anglican, and almost certainly married with children. He comes from a solidly middle class background: nine of the 44 respondents were sons of doctors, and nine sons of clergymen. He is likely to have grown up in a strongly churchgoing family, with close relatives working either in medicine or in the church. He probably formed the intention of becoming a doctor quite early in life, at about the age of 15 . Though the influence of the church might have been strong, his parents will have been the people who most shaped his choice of career. The example of

St John's College, Nottingham NG9 3 DS

KEITH LEIPER, MA, MB, theological student

Correspondence to: 55 Bridle Close, Ford, Bidston, Birkenhead L43 9UU. friends in the medical profession may well have influenced him; the advice of clergy and schoolteachers was usually less important.

The medical clergyman comes from a privileged educational background. Twenty nine respondents had attended public or independent schools, and only one had been to a comprehensive. $\mathrm{He}$ is most likely to have studied at a London medical school, often preceded by Oxbridge. (Cambridge gained a commanding lead over Oxford by 10 "mediclerics" to two.) Only five of the group entered theological college first and so entered medical school as ordained clergymen.

After qualification the medical clergymen had followed a wide range of careers in medicine. A third had worked abroad, either as missionaries or as government medical officers, and a similar proportion had acted as medical officers in the armed forces. Almost half had worked as general practitioners, while one in five had been a hospital consultant. Two of the doctors who had been ordained before entering medical school were still in junior posts in hospital medicine. Only one respondent was a psychiatrist. Between them the medical clergy had accumulated six MDs, and 12 were fellows of royal colleges.

The group was roughly equally divided into those who combined the roles of doctor and minister and those who had relinquished the practice of medicine altogether. Some missionary doctors, when family or political considerations had forced them to return to this country, had chosen that time to leave medicine and to concentrate on the pastoral ministry. Nine doctors had taken retirement from their career in the United Kingdom and had subsequently been ordained.

\section{Becoming and being a minister}

Eight doctors reported that they had thought about ordination early in their lives, in two cases before the age of 10 . The average medicleric applied for training as a minister at about the age of 45 , but there was a wide range. He received most encouragement in taking this step from friends already in the ordained ministry; 